Article

\title{
Forest-Cover Change and Participatory Forest Management of the Lembus Forest, Kenya
}

\author{
Donald Kipruto Kimutai ${ }^{1, *}$ and Teiji Watanabe ${ }^{2}$ \\ 1 Graduate School of Environmental Science, Hokkaido University, Sapporo, Hokkaido 060-0810, Japan \\ 2 Faculty of Environmental Earth Science, Hokkaido University, Sapporo, Hokkaido 060-0810, Japan; \\ teiwata@mac.com \\ * Correspondence: solitkim@yahoo.com; Tel.: +81-11-706-2213
}

Academic Editor: Yu-Pin Lin

Received: 30 April 2016; Accepted: 18 July 2016; Published: 26 July 2016

\begin{abstract}
Forests are a vital resource supporting the livelihoods of rural communities in Kenya. In spite of this significant role, human activities have put increased pressure on this resource, leading to continued forest-cover decline. To address forest-cover decline, the Kenyan government introduced Participatory Forest Management (PFM) through its Forest Department in the early 2000s, enabling local communities to form and register Community Forest Associations (CFAs). This study was conducted to examine the impacts of the PFM approach on the Lembus Forest-cover change. Three Landsat satellite images (Landsat 5 TM acquired on 9 January 1985; Landsat 7 ETM+ acquired on 1 February 2002; and Landsat 8 OLI (Operational Land Imager) acquired on 1 March 2015) were used to analyse forest-cover change in the 1st period (1985-2002) and the 2nd period (2002-2015). In analysing the contribution of CFAs in conservation and management of the Lembus Forest, questionnaire sheets were distributed randomly to various residents living adjacent to the Lembus Forest; 327 valid responses were obtained from heads of households. The results of the land-cover change show a decrease in the percentage of forest-cover decline from $11.2 \%$, registered in the 1 st period, to $8.2 \%$ in the $2 \mathrm{nd}$ period. This led to the decrease of the annual rate of the forest-cover decline from 0.4 in the 1st period to 0.2 in the 2nd period. Three CFAs operate in this area, and 75\% of the respondents participated in tree planting and $16 \%$ participated in tree pruning. This type of community participation is thought to most likely be the cause of the decline of the recent decreasing annual rate of forest-cover loss in the study area. Conversely, we found out that important initiatives, such as a forest patrol, had not been implemented due to lack of funding, and that CFAs and Kenya Forest Service had not yet signed any management agreement.
\end{abstract}

Keywords: forest-cover change; Participatory Forest Management (PFM); Community Forest Associations (CFAs); Lembus Forest

\section{Introduction}

Forests are of immense importance in the survival and development of human beings. Their enormous contributions range from air purification, to control of hydrological cycles, provision of ecosystem goods, and habitat for a great diversity of fauna [1,2]. In developing countries, forests play a significant role in supporting the livelihoods of communities living adjacent to them [3]. For example, approximately $22 \%$ of the total income for rural communities in developing countries comes from forest products [4]. A study conducted in Tigray, northern Ethiopia shows that forest products are the second largest source of income for local people after agriculture [5]. Apart from income, forests are the main source of firewood for over 2.4 billion people worldwide [3].

In the last 10 millenia, global forest-cover experienced a significant decline, going from about 6 billion ha to approximately 4 billion ha [6], although the global annual rate of decline has shown a 
decreasing trend, from $0.2 \%$ between 1990 and 2000 to $0.12 \%$ and $0.14 \%$ in the periods from 2000 to 2005 and 2005 to 2010, respectively [7]. Tropical regions have continued to experience rapid changes in forest-cover, with most regions recording high forest-cover loss compared to total forest gain [8]. In Kenya, forests are estimated to cover about $6 \%$ of the total land-cover, which is below the $10 \%$ threshold recommended by the United Nations [7]. Despite already being a low forest-cover country, Kenya has faced the additional challenge of forest-cover decline, losing approximately 241,000 ha of forest between 1990 and 2010 [7]. The loss in forest-cover has been mostly attributed to deforestation fuelled by intense human activities [9-11]. To address forest-cover decline, institutional and policy reforms were initiated to pave the way for involvement of all stakeholders in forest management.

The Participatory Forest Management (PFM) approach was first introduced as a pilot project in the Arabuko Sokoke Forest in 1997 [12,13]. The enactment of the Forest Act in 2005 not only legalized the PFM approach but also led to the formation of the Kenya Forest Service (KFS), an institution mandated to oversee the management of all state forests. Article 46(1) of the Act decrees the formation of Community Forest Associations (CFAs). The roles of the CFAs include: protection, conservation, and management of designated forests as per forest management plan, developed in line with traditional user rights and assistance in enforcing the provisions of the forest act [14].

Currently, over 325 registered CFAs are spread across the country [15]. CFAs have faced a number of challenges, which include the slow implementation of PFM, the KFS ceding minimal forest legislative powers and control of forest resources to CFAs [13,16], weak organizational structure of CFAs, conflict of interest, issues around accountability, and lack of funding, among other factors [17]. Nevertheless, a number of studies [13,18-21] have reported an improvement in the livelihoods of CFA members as compared to non-CFA members. Few studies, however, have been conducted to document the contributions of CFAs in enhancing forest-cover, specifically in the Lembus Forest, a critical water catchment area. Meanwhile, PFM has been credited with improved forest protection and regeneration in Nepal [22,23], lower rates of deforestation in community-managed forests compared to protected areas in tropical regions [24], and improved forest conservation in Mexico [25].

Forest-cover monitoring helps in quantifying the impact of different approaches on forest management. Satellite remote sensing provides spatial and temporal charecteristics of land-cover change patterns; thus, it has been widely used to map forest-cover change $[8,22,24,26,27]$. Therefore, this study applies satellite remote sensing, field observation, and a household questionnaire survey to: (1) analyse forest-cover change before and after the introduction of PFM; (2) identify factors driving the change; and (3) analyse the contribution of the CFAs in enhancing the Lembus Forest-cover.

\section{Materials and Methods}

\subsection{Study Area}

The Lembus Forest is located in the Eldama-Ravine sub-county, Baringo County in western Kenya (Figure 1). It lies between latitudes $0^{\circ} 4^{\prime} \mathrm{S}$ and $0^{\circ} 8^{\prime} \mathrm{N}$ and longitudes $35^{\circ} 32^{\prime} \mathrm{E}$ and $35^{\circ} 48^{\prime} \mathrm{E}$. The forest was "gazetted" (which means reserved for purposes other than forestry) in 1932 and is currently owned by the government. The forest is the main source of the Perkerra River, which supplies water to the Perkerra irrigation system. Additionally, recent construction of the Chemususu dam with the water capacity of 12 million $\mathrm{m}^{3}$ places this forest as a critical water catchment area.

The forest is made up of three major forest blocks; namely, Chemorgok, Chemususu, and Narasha Forest blocks, covering an area of approximately 21,232 ha in total. The forest is located at an altitude of $2391 \mathrm{~m}$ and receives a mean annual rainfall between $1200 \mathrm{~mm}$ and $1800 \mathrm{~mm}$. The mean annual air temperature ranges from $10{ }^{\circ} \mathrm{C}$ to $24^{\circ} \mathrm{C}$. The Lembus Forest blocks form part of the Mau forest complex, the country's largest closed canopy forest ecosystem, home to a great diversity of flora and fauna. The forest comprises both natural and plantation forest zones. The natural forest zones are dominated by indigenous tree species, which include Syzygium guinensis, Prunus africana, Podocarpus falcatus, Podocarpus latifolia, Olea africana, Albizia gumifera, Juniperus procera, 
Polysiscia kikuyensis, Dobeya torida, Olea capensis, and Viprous species. Plantation zones consist of exotic tree species such as Eucalyptus saligina, Cupressus lustanica, and Pinus patula.

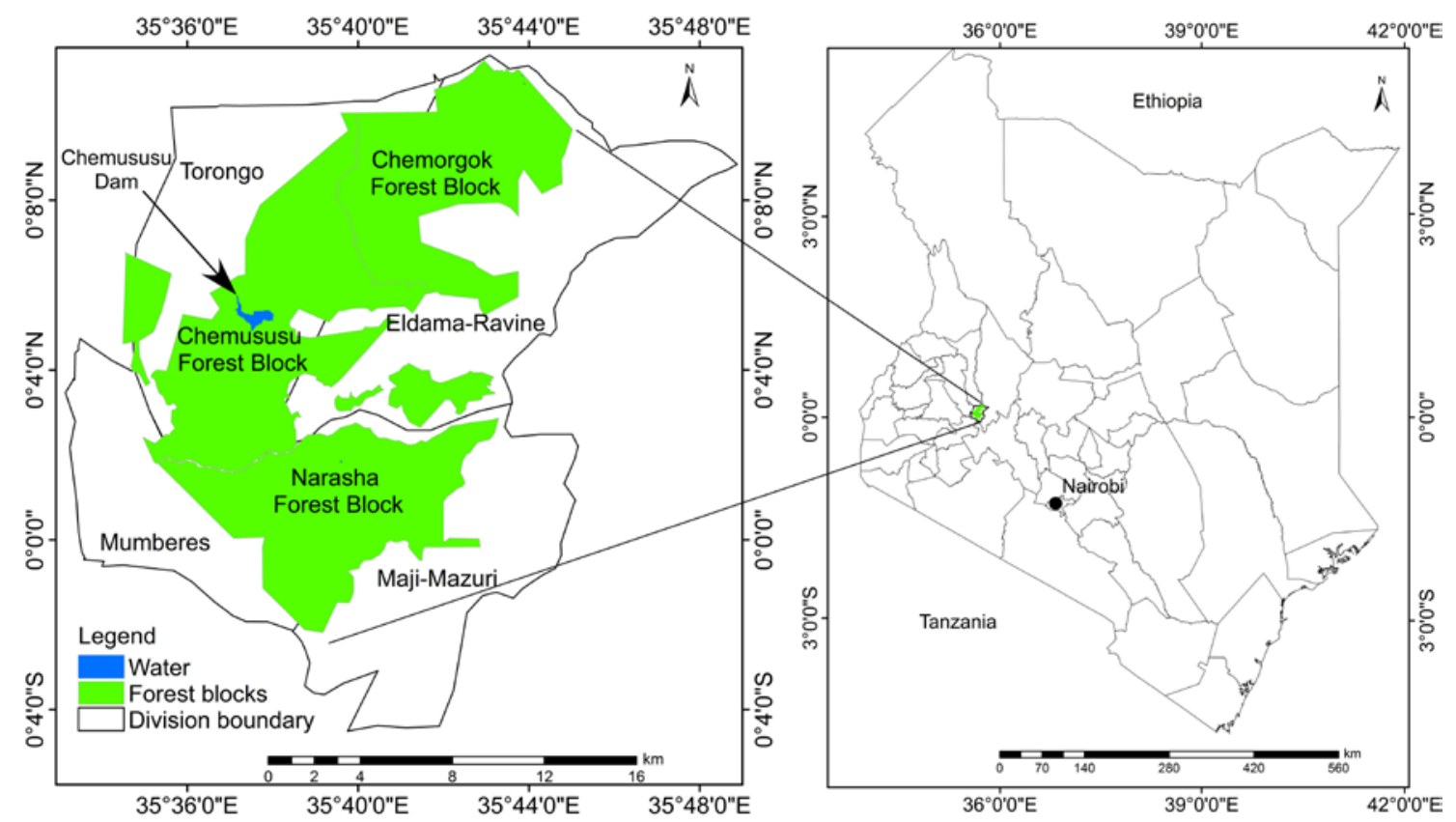

Figure 1. Geographic location and extent of the Lembus Forest.

\subsection{Social Survey}

The study utilised both primary and secondary data sets. The primary data included household questionnaire survey data. These questionnaires were administered to the respondents, who were mainly household heads living within the Torongo and Eldama-Ravine divisions (Figure 1). The two divisions have about 1593 and 2986 households, respectively. Therefore, in total there are approximately 4559 households in the two divisions [28]. The sample size was calculated using Cochran's (1963:75) formula [29] below:

$$
n=\frac{Z^{2} P(1-P)}{e^{2}}
$$

where $n$ is the Sample size; $Z^{2}$ is a constant (Abscissa of normal curve that cuts off an area $\alpha$ at the tails, the value is found in statistical tables); $e^{2}$ is the level of precision, and $p$ is the estimated proportion of an attribute. From the formula, the sample size was found to be 385 respondents; however, $20 \%$ of the total questionnaires were added on top to take care of unreturned and invalid questionnaires. Thus, 500 households (170 and 330 households from Torongo and Eldama-Ravine, respectively) were sampled. We used a stratified sampling design, where each division was taken as a stratum and households within $5 \mathrm{~km}$ from the forest boundary were administered questionnaires at a systematic random sample rate of every 10 th household $(4559 / 500=10$ th periodic interval). Forest-adjacent communities living within $5 \mathrm{~km}$ of the forest boundary rely primarily on forest resources [30]. The first household was randomly selected from the forest edge in each stratum, 10 households were skipped, and the 11th household sampled; the same process was repeated throughout the study area. In this study the respondents (i.e., "household heads") refers to the person in charge or leading the family (man or woman). In the culture of the local community, men determine and influence the activities and decisions affecting the whole household. The questionnaire was structured to capture socio-economic attributes of the respondents, forest use, threats facing the forest, CFA membership, and their contributions in forest conservation and management. The study was limited with time constraints, thus it was difficult to organize or arrange focused group discussions. We were not able to organize meetings within our 
limited time frame due to the need for prior negotiations with community leaders. Nevertheless, key informants-namely, CFA leaders (the chairman, treasurer, and secretary), the deputy district forest officer, three forest managers and one officer in charge of enforcement and compliance, and lastly three elders per forest block were interviewed. The interviews were carried out with the view of obtaining information on the current and previous forest-cover, drivers of forest-cover change, and the roles and contributions of CFAs in forest conservation and management. Moreover, secondary data, such as forest crime data and the number of CFAs, were obtained from the Eldama-Ravine KFS station.

\subsection{Satellite Remote Sensing}

Cloud-free satellite images from1985, 2002, and 2015-all of which were acquired during the dry season (December to March) — were selected for the study. The images were obtained from the United States Geological Survey (USGS) Global Visualization Viewer website (www.glovis.usgs.gov). A topographic map of 1972 and the Kenya forest-cover shapefiles were obtained from the Survey of Kenya and KFS, respectively. The main datasets used are summarized in Table 1.

Table 1. Landsat images, maps, and secondary data used in the study. KFS: Kenya forest service.

\begin{tabular}{ccccc}
\hline Image/Maps/Data & Path & Row & Date of Acquisition & Sources \\
\hline Landsat 5 TM & 169 & 060 & 09 January 1985 & USGS ** \\
Landsat 7 ETM+ & 169 & 060 & 01 February 2002 & USGS \\
Landsat 8 OLI * & 169 & 060 & 01 March 2015 & USGS \\
Forest shapefiles & - & - & - & KFS Surveyors \\
Topographic map & - & - & 1972 & Kenya Survey \\
\hline \multicolumn{4}{c}{ * OLI: Operational Land Imager, ${ }^{* *}$ USGS: United States Geological Survey. }
\end{tabular}

The spectral bands of the selected Landsat images were individually imported to ArcGIS 10.2. The spectral bands $1-5$ and 7 were chosen for Landsat 5 and 7, while bands 2-7 were used for Landsat 8 . These selected spectral bands were co-registered to Universal Transverse Mercator (UTM) zone 36N. Later, atmospheric correction was performed in order to minimize the effect of gain and bias upon the images [31]. Atmospheric corrections involved conversion of the digital numbers (DN) to "top of atmosphere" (TOA) or surface reflectance [32,33]. The acquired forest shapefiles and the topographic map of 1972 were used to clip out the study area from the pre-processed Landsat imageries. To aid in identification of dominant land-cover types, unsupervised classification was performed in ArcGIS 10.2. Using the results of unsupervised classification, Google Earth imagery, and our familiarity of the study area, four land-cover classes (closed forest, open forest, grassland, and barren land) were identified for Landsat images from 1985 and 2002. For 2015 imagery, five land-cover classes (closed forest, open forest, grassland, barren land, and water) were used.

Vegetation indices, especially the Normalized Difference Vegetation Index (NDVI), have been extensively used to analyse and discriminate vegetation cover [34-38]. To utilise this gain, NDVI analysis was performed, and the resulting NDVI maps were reclassified based on the NDVI threshold $[39,40]$. Furthermore, the resulting NDVI maps and high-resolution imagery (Google Earth) were utilised to develop spectral signatures for the land-cover types shown in Table 2. Finally, supervised classification using the maximum likelihood classifier algorithm (MLC) contained in ArcGIS 10.2 was used to generate forest-cover maps. Then, post-classification analysis was carried out to establish land-cover change trajectories within the study area. To calculate the rate of the forest-cover changes, we reclassified the land-cover maps into two land cover types: (1) forest (comprising closed and open forests); and (2) non-forest (consisting of barren land, grassland, and water). To calculate the annual rate of change on the resulting land-cover classes, we applied the formula below [41]:

$$
r=\left\{\frac{1}{t 2-t 1}\right\} \times \ln \left\{\frac{A 2}{A 1}\right\}
$$


where $A 2$ and $A 1$ refer to forest area at the end and beginning of the analysis period, respectively, and $t 2$ and $t 1$ correspond to the year in the end and beginning of the analysis.

Table 2. Land-cover classification scheme.

\begin{tabular}{ll}
\hline Land-Cover & Description \\
\hline Closed Forest & Densely vegetated areas characterised by overlapping tree canopies \\
Open Forest & Sparsely vegetated areas dominated by shrubs and scattered trees \\
Grassland & Areas covered with grass \\
Barren Land & Areas without vegetation cover-e.g., rocky and bare grounds \\
Water & Areas with water bodies \\
\hline
\end{tabular}

A change detection analysis was also performed on the forest and non-forest-cover types, and the resulting areas of change were categorized into two: (1) "recovered" which means areas that were non-forest in the previous image, but were later converted to forest in the subsequent image; and (2) "declined", representing areas that were forest in the previous image, but later converted to non-forest in the later image.

\section{Results}

\subsection{Areas and Change Rates of Land-Cover Types}

The results displayed in Figure 2 clearly show that closed forest has remained the dominant land-cover in the Lembus Forest throughout the study period. Although the cover progressively declined from the initial study area (amount of $72.3 \%$ in 1985 to $68.6 \%$ in 2015), it continued to predominate other land-cover types. The results also show that open forest was the second largest land-cover (14.8\%) in 1985 but declined significantly to 10.3\% in 2015. Grassland showed a slight increase, covering $4.8 \%$ in 1985 and increasing to $5.8 \%$ in 2015 . Barren land showed a significant increase from $8.1 \%$ in 1985 to $15 \%$ in 2015 . The area per land-cover class is summarised in Table 3.

Table 3. Summary of the area and percentage of land-cover types.

\begin{tabular}{ccccccc}
\hline \multirow{2}{*}{ Land-Cover Types } & \multicolumn{2}{c}{1985} & \multicolumn{2}{c}{$\mathbf{2 0 0 2}$} & \multicolumn{2}{c}{$\mathbf{2 0 1 5}$} \\
\cline { 2 - 7 } & Area (ha) & $\mathbf{\%}$ & Area (ha) & $\mathbf{\%}$ & Area (ha) & $\mathbf{\%}$ \\
\hline Water & 0.0 & 0.0 & 0.0 & 0.0 & 66.7 & 0.3 \\
Closed Forest & $15,342.2$ & 72.3 & $15,047.7$ & 70.9 & $14,575.1$ & 68.6 \\
Open Forest & 3149.1 & 14.8 & 2235.2 & 10.5 & 2177.6 & 10.3 \\
Grassland & 1024.9 & 4.8 & 1964.0 & 9.2 & 1224.2 & 5.8 \\
Barren Land & 1716.6 & 8.1 & 1985.9 & 9.4 & 3189.2 & 15.0 \\
Total & $21,232.8$ & 100.0 & $21,232.8$ & 100.0 & $21,232.8$ & 100.0 \\
\hline
\end{tabular}

Table 4 shows a significant variation in the annual rates of change among the land-cover types in both the 1st and 2nd periods. In the 1st period, closed forest declined at an annual rate of $-0.1 \%$, as compared to the 2 nd period, which experienced a slight increase in the annual rate of change to $-0.2 \%$. Open forest decreased at an annual rate of $-2.0 \%$ and $-0.2 \%$ in the 1 st and 2 nd periods, respectively. Grassland varied significantly, rapidly increasing at an annual rate of 3.8\% during the 1 st period, but subsequently declining at an annual rate of $-3.6 \%$ in the 2 nd period. Barren land experienced a slight increase at the rate of $0.9 \%$ in the 1 st period and a sharp increase at the rate of $3.6 \%$ in the 2 nd period. 



Figure 2. Land-cover maps of the Lembus Forest in (a) 1985; (b) 2002; and (c) 2015.

Table 4. Annual rate of change per land-cover class during the two periods.

\begin{tabular}{ccc}
\hline Land-Cover Types & \multicolumn{2}{c}{ Annual Rate of Change (\%) } \\
\hline Land-Cover & 1st Period (1985-2002) & 2nd Period (2002-2015) \\
Closed Forest & -0.1 & -0.2 \\
Open Forest & -2.0 & -0.2 \\
Grassland & 3.8 & -3.6 \\
Barren Land & 0.9 & 3.6 \\
\hline
\end{tabular}

\subsection{Land-Cover Change Trajectories}

It is evident that inter-class exchanges occurred among land-cover types in the 1st and 2nd periods. These interchanges resulted in gains (increase in land-cover) and losses (decrease in land-cover). In the 1st period, $10.9 \%$ (2314 ha) of closed forest was converted to barren land, open forest, and grassland. Open forest, on the other hand, lost 6.6\% (1401 ha) and 2.4\% (510 ha) to closed forest and barren land, respectively, in the 1st period. The 2 nd period saw $7.9 \%$ (1677 ha) of closed forest convert to 
barren land, open forest, and water. Additionally during this period, 4.8\% (1019 ha), 2.4\% (510 ha), and $3.4 \%$ (722 ha) of grassland, open forest, and closed forest, respectively, were converted to barren land. These inter-class exchanges are displayed in Table 5 with the diagonals in bold showing the percentage of land-cover that did not change to another class.

Table 5. Land-cover change matrix as percentage of the study area $(21,232.8 \mathrm{ha})$.

\begin{tabular}{cccccc}
\hline \multirow{2}{*}{1985 Land-Cover Types } & \multicolumn{5}{c}{ 2002 Land-Cover Types } \\
\cline { 2 - 6 } & Closed Forest & Open Forest & Grassland & Barren Land \\
\hline Closed Forest & $\mathbf{6 1 . 4}$ & 4.1 & 2.9 & 3.9 \\
Open Forest & 6.6 & 3.8 & 2.1 & 2.4 \\
Grassland & 1.0 & 1.1 & $\mathbf{1 . 9}$ & 0.9 \\
Barren Land & 1.9 & 1.5 & 2.4 & $\mathbf{2 . 2}$ \\
\hline \multirow{2}{*}{$\mathbf{2 0 0 2}$ Land-Cover Types } & Closed Forest & Open Forest & Grassland & Barren Land & Water \\
\cline { 2 - 6 } & $\mathbf{6 2 . 7}$ & 4.2 & 0.4 & 3.4 & 0.3 \\
Closed Forest & 3.1 & $\mathbf{3 . 3}$ & 1.7 & 2.4 & 0.0 \\
Open Forest & 0.8 & 1.5 & $\mathbf{2 . 1}$ & 4.8 & 0.0 \\
Grassland & 2.1 & 1.3 & 1.5 & $\mathbf{4 . 4}$ & 0.0 \\
Barren Land & \multicolumn{7}{c}{}
\end{tabular}

\subsection{Accuracy Assessment}

We conducted an accuracy assessment of the 2015 classified satellite image first by randomly sampling 50 points per land-cover class within the study area. Later, the sampled points were verified during a field visit, although it was difficult to physically verify all points due to the presence of deep valleys and thick bushes. To counter this shortcoming, the inaccessible points were verified using Google Earth imagery. The verified points were later compared with the same points in the classified map of 2015 by means of a confusion matrix, as shown in Table 6 . It should be noted, however, that it was difficult to ascertain the accuracy of 1985 and 2002 classified imageries due to lack of aerial photographs and clear Google Earth imagery. Nevertheless, interviews conducted during the field survey aided in the development of the training sites for 1985 and 2002 imageries. The overall accuracy for the 2015 Landsat 8 classified image was calculated from Table 6 by dividing the correctly classified pixels by the total number of the pixels-i.e., $(222 / 251) \times 100=88.45 \%$. Furthermore, Kappa for the 2015 Landsat 8 classified image-which was calculated by the Kappa formula provided by [42] — was found to be $85.54 \%$.

Table 6. Confusion matrix accuracy.

\begin{tabular}{|c|c|c|c|c|c|c|c|}
\hline \multirow{8}{*}{$\begin{array}{l}\text { Classified } \\
\text { Image }\end{array}$} & \multicolumn{7}{|c|}{ Reference Data } \\
\hline & Land-Cover & Water & Barren Land & Closed Forest & Open Forest & Grassland & Row Totals \\
\hline & Water & 49 & 0 & 1 & 0 & 0 & 50 \\
\hline & Barren Land & 0 & 48 & 0 & 0 & 2 & 50 \\
\hline & Closed Forest & 0 & 1 & 49 & 1 & 0 & 51 \\
\hline & Open Forest & 0 & 0 & 15 & 29 & 5 & 49 \\
\hline & Grassland & 0 & 4 & 0 & 0 & 47 & 51 \\
\hline & Column Total & 49 & 53 & 65 & 30 & 54 & 251 \\
\hline
\end{tabular}

\subsection{Forest-Cover Change Detection}

To investigate the forest-cover changes occurring in both the 1 st and 2 nd periods, we reclassified land-cover into two main classes: (1) forest and (2) non-forest. Table 7 shows that the forest covered $87.1 \%$ of the total area in 1985 , but it progressively declined to $81.4 \%$ in 2002 at an annual rate of $0.4 \%$. Non-forest, on the other hand, drastically increased at an annual rate of $2.1 \%$ from the initial cover of $12.9 \%$ in 1985 to $18.6 \%$ in 2002 . Furthermore, forest declined at an annual rate of $0.2 \%$ to occupy $78.9 \%$ 
of the total area in 2015, while non-forest slightly increased at an annual rate of $1 \%$ to cover $21.8 \%$ of the total area.

Table 7. Annual forest-cover change detection.

\begin{tabular}{cccccccccc}
\hline \multirow{2}{*}{ Land-Cover Type } & \multicolumn{2}{c}{$\mathbf{1 9 8 5}$} & \multicolumn{2}{c}{$\mathbf{2 0 0 2}$} & \multicolumn{2}{c}{$\mathbf{2 0 1 5}$} & \multicolumn{3}{c}{ Annual Rate of Change (\%) } \\
\cline { 2 - 9 } & Area (ha) & $\mathbf{\%}$ & Area (ha) & $\mathbf{\%}$ & Area (ha) & $\mathbf{\%}$ & 1st Period & 2nd Period \\
\hline Forest & $18,491.3$ & 87.1 & $17,282.9$ & 81.4 & $16,752.6$ & 78.9 & -0.4 & -0.2 \\
Non-forest & 2741.5 & 12.9 & 3949.9 & 18.6 & 4480.2 & 21.1 & 2.1 & 1.0 \\
\hline
\end{tabular}

\subsection{Forest-Cover Change Dynamics}

The Lembus Forest experienced dynamic changes in its land-cover as a result of forest recovery in some areas (land-cover changes from non-forest to forest) and forest decline in other areas (land-cover changes from forest to non-forest). It is clear that the land-cover changes occurred at different temporal and spatial scales. The changes per forest block were analysed to articulate the forest-cover change dynamics within the Lembus Forest.

\subsubsection{Chemorgok Forest Block}

The Chemorgok Forest Block maintained the majority of its forest-cover (Figure 3). Although the block experienced a $4.6 \%$ decline in the 1st period, the percentage of forest-cover decreased to $2.3 \%$ in the 2nd period. Furthermore, the percentage of forest recovery showed a slight increase from $2.9 \%$ in the 1 st period to $2.7 \%$ in the 2 nd period (Table 8 ).
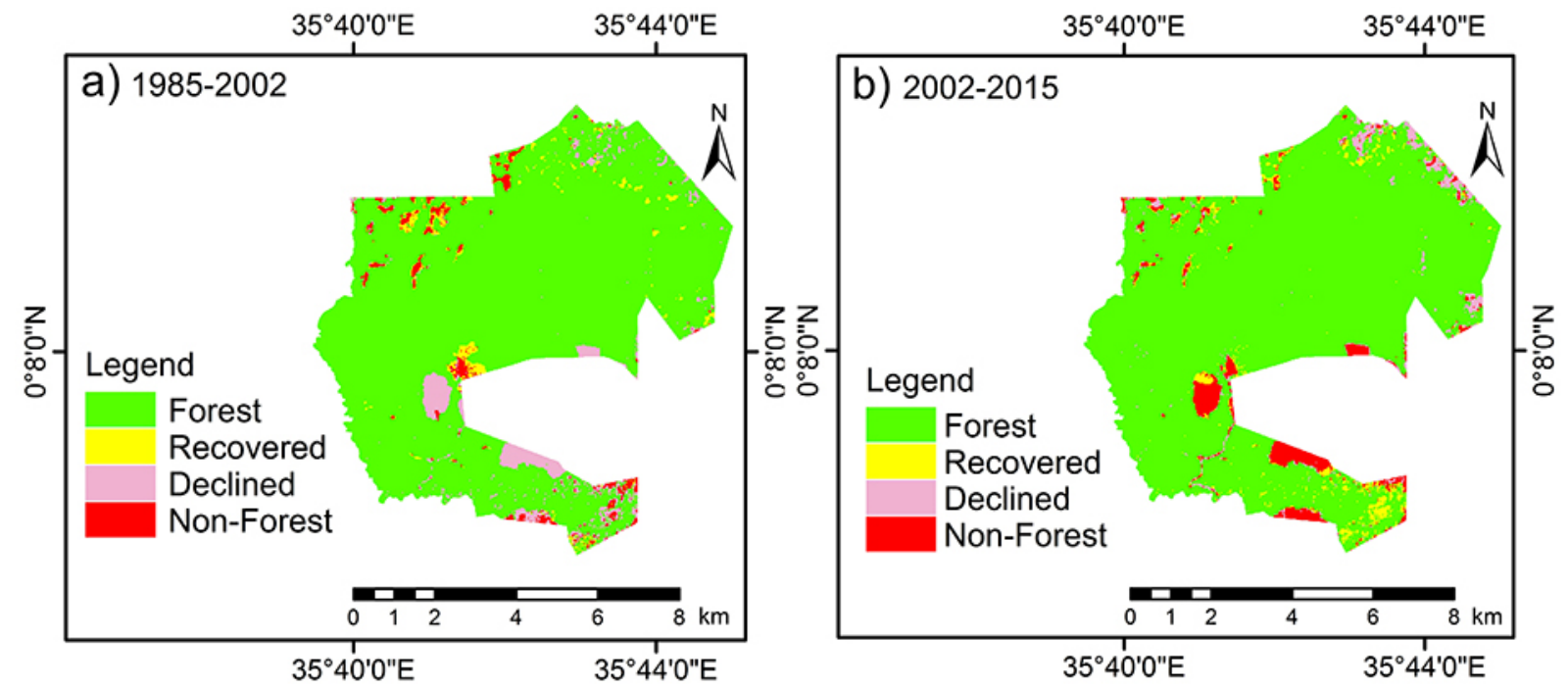

Figure 3. Forest-cover changes in the Chemorgok Forest Block in the (a) 1st and (b) 2nd periods.

Table 8. Forest-cover changes in the Lembus Forest blocks in the 1st and 2nd periods.

\begin{tabular}{|c|c|c|c|c|c|c|c|c|c|c|c|c|}
\hline \multirow{3}{*}{$\begin{array}{l}\text { Forest-Cover } \\
\text { Changes }\end{array}$} & \multicolumn{4}{|c|}{ Chemorgok Forest Block } & \multicolumn{4}{|c|}{ Chemususu Forest Block } & \multicolumn{4}{|c|}{ Narasha Forest Block } \\
\hline & \multicolumn{2}{|c|}{ 1st Period } & \multicolumn{2}{|c|}{ 2nd Period } & \multicolumn{2}{|c|}{ 1st Period } & \multicolumn{2}{|c|}{ 2nd Period } & \multicolumn{2}{|c|}{ 1st Period } & \multicolumn{2}{|c|}{ 2nd Period } \\
\hline & $\begin{array}{l}\text { Area } \\
\text { (ha) }\end{array}$ & $\%$ & $\begin{array}{c}\text { Area } \\
\text { (ha) }\end{array}$ & $\%$ & $\begin{array}{c}\text { Area } \\
\text { (ha) }\end{array}$ & $\%$ & $\begin{array}{c}\text { Area } \\
\text { (ha) }\end{array}$ & $\%$ & $\begin{array}{c}\text { Area } \\
\text { (ha) }\end{array}$ & $\%$ & $\begin{array}{l}\text { Area } \\
\text { (ha) }\end{array}$ & $\%$ \\
\hline Forest & 5438.6 & 91.2 & 5418.8 & 90.8 & 6904.0 & 83.7 & 6779.7 & 82.1 & 3812.4 & 54.4 & 3390.1 & 48.3 \\
\hline Recovered & 119.1 & 2.0 & 160.8 & 2.7 & 439.5 & 5.3 & 192.0 & 2.3 & 604.7 & 8.6 & 861.1 & 12.3 \\
\hline Declined & 275.7 & 4.6 & 138.9 & 2.3 & 480.9 & 5.8 & 563.8 & 6.8 & 1603.8 & 22.9 & 1027.0 & 14.6 \\
\hline Non-Forest & 132.0 & 2.2 & 246.9 & 4.1 & 430.4 & 5.2 & 719.3 & 8.8 & 991.7 & 14.1 & 1734.4 & 24.7 \\
\hline Total & 5965.4 & 100.0 & 5965.4 & 100.0 & 8254.8 & 100.0 & 8254.8 & 100.0 & 7012.6 & 100.0 & 7012.6 & 100.0 \\
\hline
\end{tabular}




\subsubsection{Chemususu Forest Block}

Figure 4 illustrates that a large percentage of the Chemususu Forest Block maintained its vegetation cover in both the 1st and 2nd periods. Table 8 shows a slight increase in the percentage of forest-cover decline from $5.8 \%$ in the 1 st period to $6.8 \%$ in the 2 nd period.
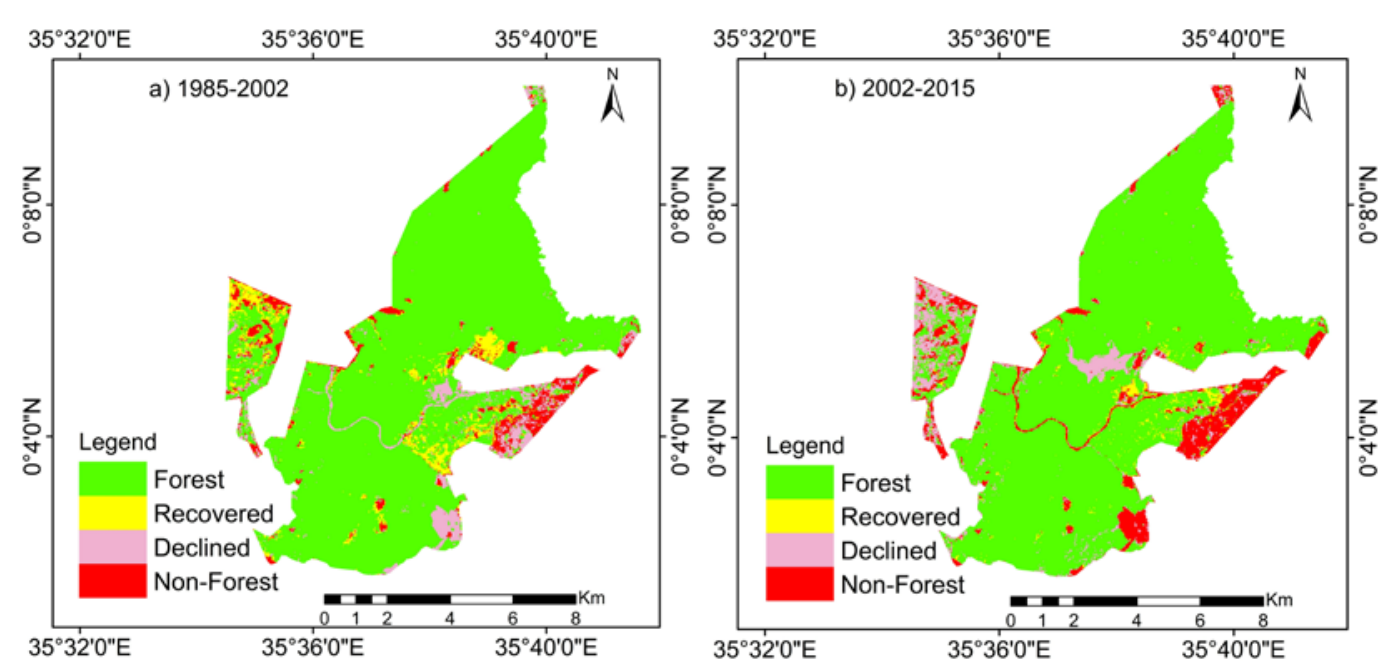

Figure 4. Forest-cover changes in the Chemususu Forest Block in the (a) 1st and (b) 2nd periods.

\subsubsection{Narasha Forest Block}

Figure 5 shows that the forest in the Narasha Forest Block has been highly fragmented. The forest has lost a significant amount of its land-cover in both the 1st and 2nd periods. Table 8 shows that the forest massively declined by $22 \%$ and $14 \%$ in the 1 st and 2 nd periods, respectively.
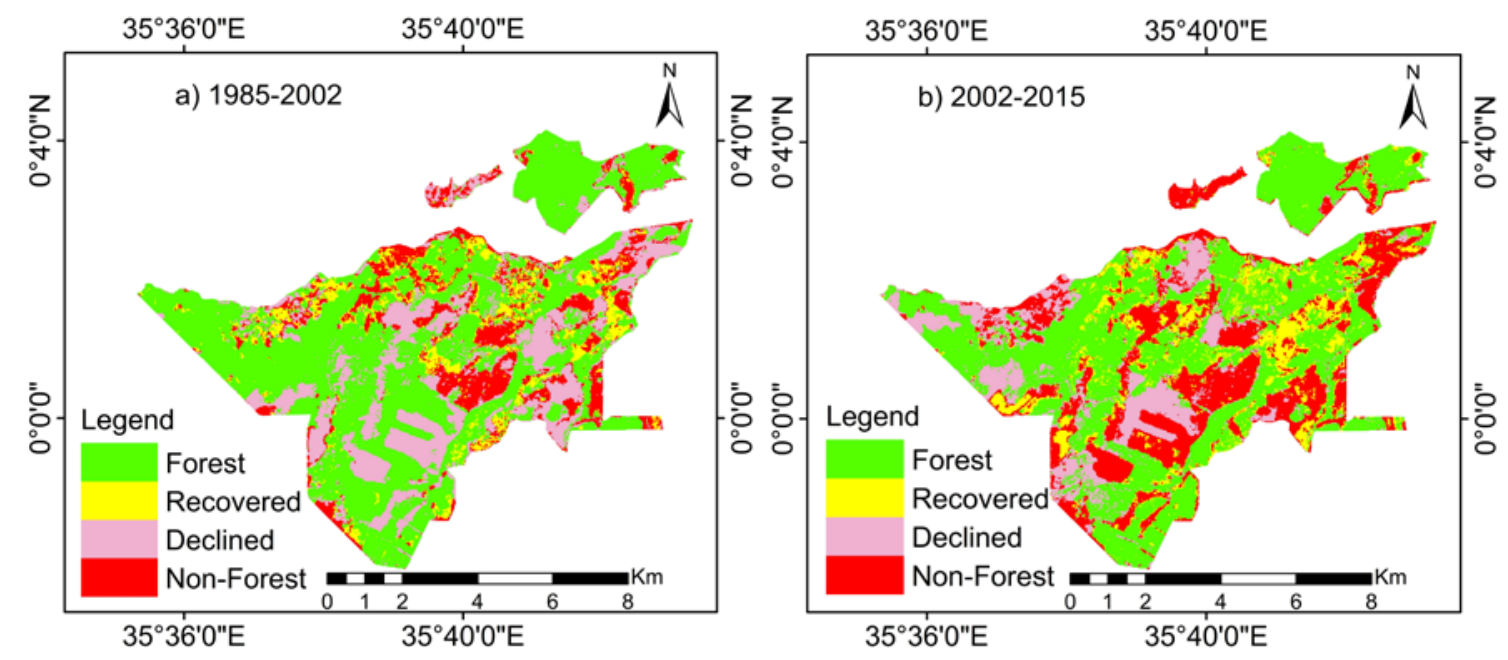

Figure 5. Forest-cover changes in the Narasha Forest Block in the (a) 1st and (b) 2nd periods.

\subsection{CFAs Operating in the Lembus Forest}

Community participation in forest management first started in the Lembus Forest in the early 2000s. At that time, forest associations had not yet been registered due to lack of relevant laws to support their registration. The enactment of the 2005 Forest Act in 2007 paved the way for the registration of three CFAs in 2008. Each of the three CFAs was allocated a forest block, as shown in Table 9. The CFA members have been subdivided into forest user groups-namely, grazers, beekeepers, fuel wood collectors, Plantation Establishment and Livelihood Improvement 
Scheme (PELIS), tree seedling producers, fish farmers, and herbalists. Members elect their leaders (chairman, treasurer, secretary, and one representative per user group) every three years. During field visits, we noted that two CFAs-i.e., Lembus Chemususu Community Forest Association (LCCFA) and Tulwob Lembus Community Forest Association (TLCFA)—had proper leadership in place, while Lembus Narasha Community Forest Association (LENCOFA) had no leadership in place and thus there were no records to show the number of registered members. The CFAs do not have a reliable source of funds and have to rely only on donor funding (which at times may not be forthcoming) and membership subscriptions of one hundred shillings per year. The resulting lack of funds makes it difficult to pay people involved in the maintenance and management of the nurseries; hence, the tree nurseries of the LCCFA and LENCOFA are poorly managed and maintained.

Table 9. Registered community forest associations (CFAs) operating in the Lembus Forest blocks.

\begin{tabular}{|c|c|c|c|c|c|c|}
\hline \multirow{2}{*}{$\begin{array}{c}\text { Community Forest } \\
\text { Association }\end{array}$} & \multirow{2}{*}{$\begin{array}{c}\text { Year of } \\
\text { Registration }\end{array}$} & \multicolumn{3}{|c|}{ Number of Membership } & \multirow{2}{*}{$\begin{array}{l}\text { Number of } \\
\text { Households } \\
\text { (KNBS, 2009) } \\
\end{array}$} & \multirow{2}{*}{$\begin{array}{c}\text { Designated } \\
\text { Forest of } \\
\text { Operation } \\
\end{array}$} \\
\hline & & Male & Female & Total & & \\
\hline $\begin{array}{l}\text { Tulwob Lembus } \\
\text { Community Forest } \\
\text { Association (TLCFA) }\end{array}$ & 2008 & 294 & 266 & 560 & 1248 & $\begin{array}{l}\text { Chemorgok } \\
\text { Forest Block }\end{array}$ \\
\hline $\begin{array}{l}\text { Lembus Chemususu } \\
\text { Community Forest } \\
\text { Association (LCCFA) }\end{array}$ & 2008 & 337 & 237 & 574 & 4241 & $\begin{array}{l}\text { Chemususu } \\
\text { Forest Block }\end{array}$ \\
\hline $\begin{array}{c}\text { Lembus Narasha } \\
\text { Community Forest } \\
\text { Association (LENCOFA) }\end{array}$ & 2008 & \multicolumn{3}{|c|}{$\begin{array}{l}\text { No exact number was } \\
\text { available (estimated } \\
\text { number }>1000)\end{array}$} & 7623 & $\begin{array}{c}\text { Narasha } \\
\text { Forest Block }\end{array}$ \\
\hline
\end{tabular}

\subsection{Challenges Facing Lembus Forest Management}

Incidents of illegal logging were reported in all three forest blocks (Table 10). The data provide evidence that the Lembus Forest is faced with a challenge of illegal logging, although there are only limited crime data, reporting from December 2012 to June 2015, when the field survey was conducted.

Table 10. Crime reported between December 2012 and June 2015.

\begin{tabular}{cccc}
\hline \multirow{2}{*}{ Type of Crime } & \multicolumn{3}{c}{ Forest Block } \\
\cline { 2 - 4 } & Chemorgok & Chemususu & Narasha \\
\hline Illegal logging & 8 & 17 & 25 \\
Encroachment & 0 & 0 & 1 \\
Charcoal burning & 2 & 1 & 5 \\
Total & 10 & 18 & 31 \\
\hline
\end{tabular}

Data source: KFS Eldama-Ravine forest station crime reports as of 2015.

\subsection{Socio-Economic Attributes of the Respondents}

The study faced a challenge in collecting all the responses, as some respondents failed to return the questionnaires and, due to time limit, we could not administer new questionnaires to these respondents. Therefore, out of 500 administered questionnaires, we managed to obtain 327 valid responses. Though it is smaller than expected (385), the response obtained was assumed to be representative because the questionnaire had been randomly distributed.

The majority of survey respondents $(76 \%)$ were male, and the remainder $(24 \%)$ was female. The result obtained from the questionnaire survey shows that $62 \%$ of the people living adjacent to the Lembus Forest are members of CFAs and most of them became members in order to benefit from PELIS, a community participation programme promoting forest conservation while enhancing food 
security. The remaining 38\% (123 respondents) have not joined any CFAs. Figure 6 reveals that lack of awareness of how to join and the operations of CFAs within the Lembus Forest are the two top factors hindering local community involvement. Figure 7 shows that the divisions bordering the Lembus Forest continue to experience population increases. This increasing trend in population may be linked to higher dependency on the forest resources, especially with agriculture being the main economic activity (Figure 8). Local communities are highly dependent on the forest for livestock grazing, as shown in Figure 9. Furthermore, the local people rely heavily on the forest as their main source of firewood (Figure 10).

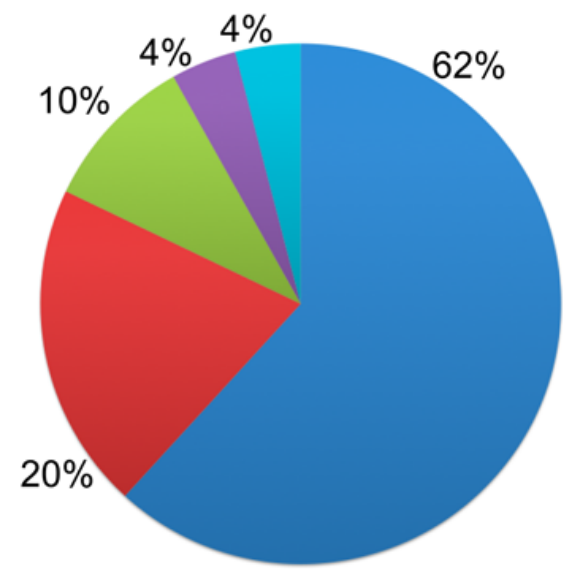

Lack of awareness on
membership bid

Lack of knowledge on

CFA operations

Lack of membership

fee

Lack of interests

Lack of benefits to members

Figure 6. Factors hindering people from joining CFAs as of 2015, identified by the questionnaire survey $(n=123)$.

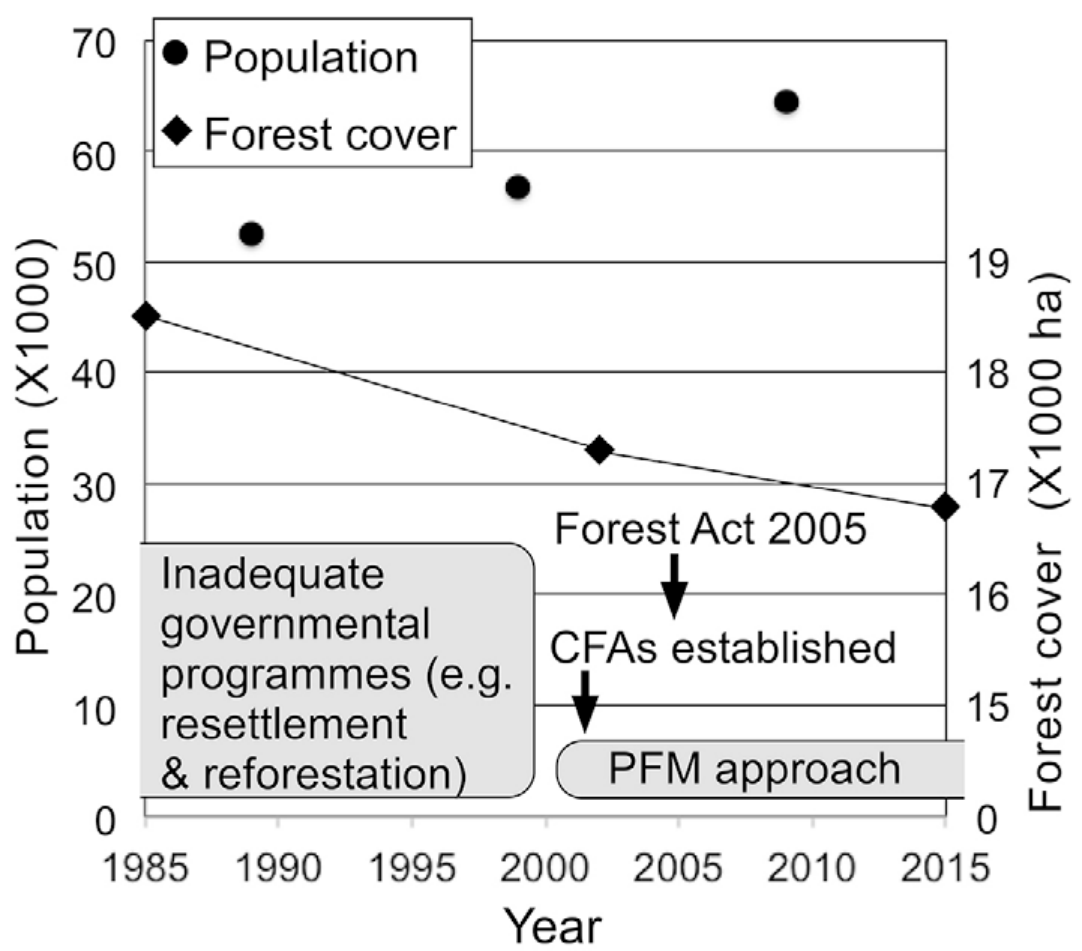

Figure 7. Relationship between the change of forest-cover decline rates and some important driving factors. Population data of the Torongo, Maji-Mazuri, Mumberes, and Eldama-Ravine divisions were supplied by the KNBS. PFM: participatory forest management. 


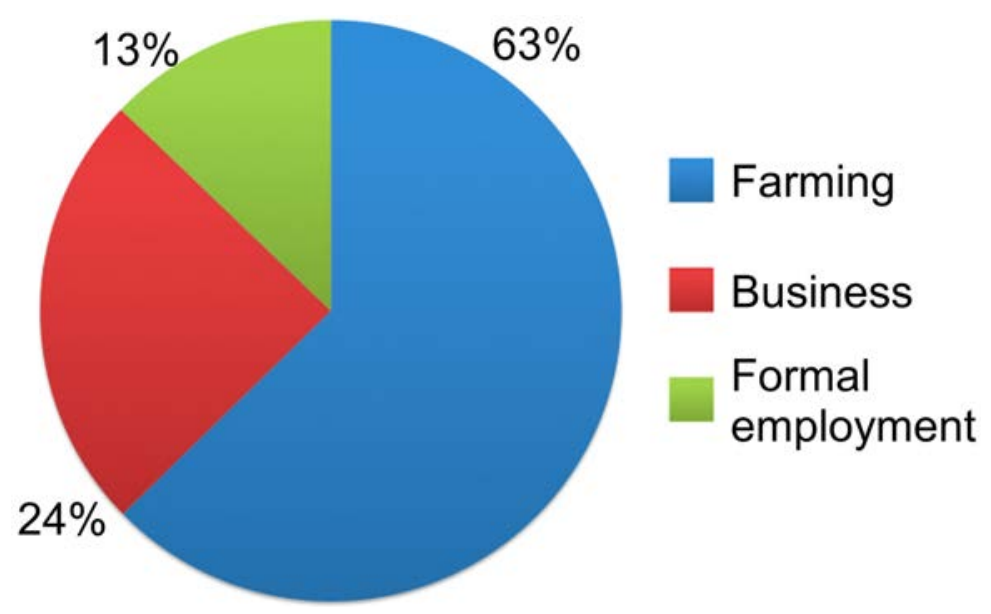

Figure 8. Economic activities of the local communities as of 2015, identified during questionnaire survey $(n=327)$.

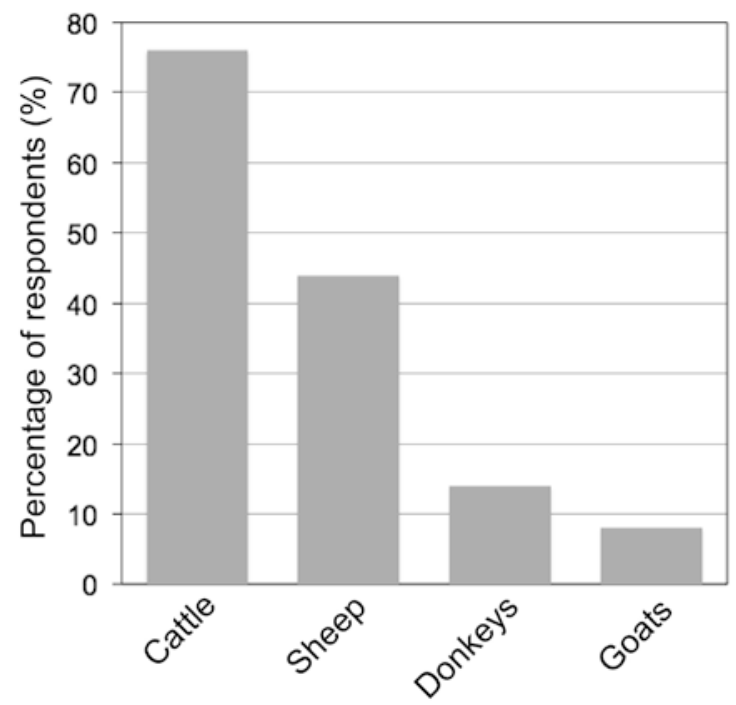

Figure 9. Percentage of respondents utilising forest to graze various livestock as of 2015, identified by the questionnaire survey $(n=327)$.

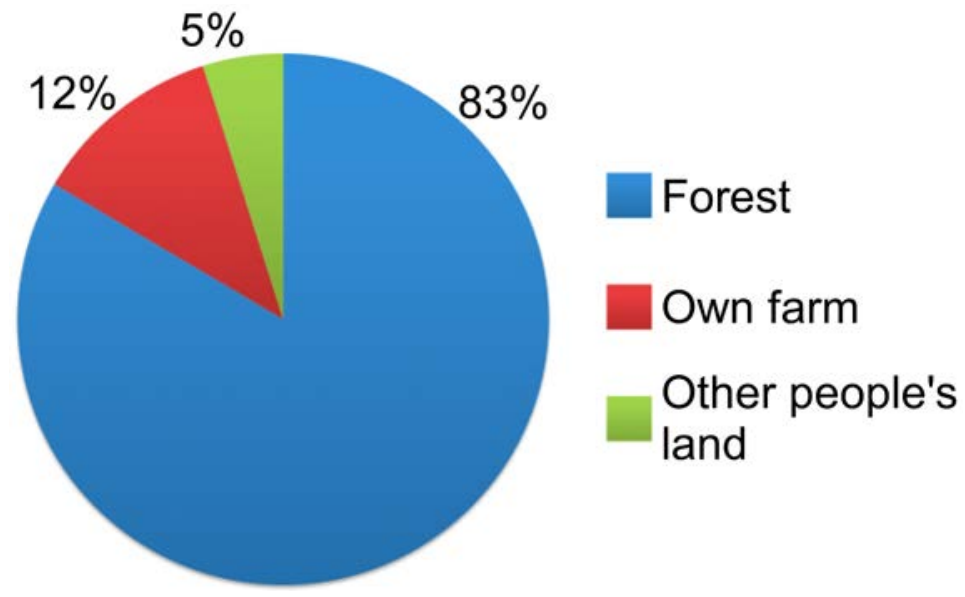

Figure 10. Places for collecting firewood as of 2015, identified during the questionnaire survey $(n=327)$. 


\subsection{CFAs Operations in the Lembus Forest}

The three CFAs have made significant contributions in the reforestation programmes within the Lembus Forest. Figure 11 shows that the majority of CFA members (74\%) have been involved in tree planting and 16\% have taken part in tree pruning. The increased participation of members in reforestation programmes was a result of the PELIS programme. With the PELIS programme, CFA members are allocated about 0.2 ha of forest-land without trees to cultivate and plant crops for three years. On the third year, members must plant and care for trees in their designated plots in order to continue growing crops in the same plot. Hence, new tree plantations are now emerging within the Lembus Forest (Figure 12). Although the CFAs have played an active role in reforestation activities, other equally important roles, such as a forest patrol, which aids in curbing illegal logging, are still lagging behind (Figure 11).

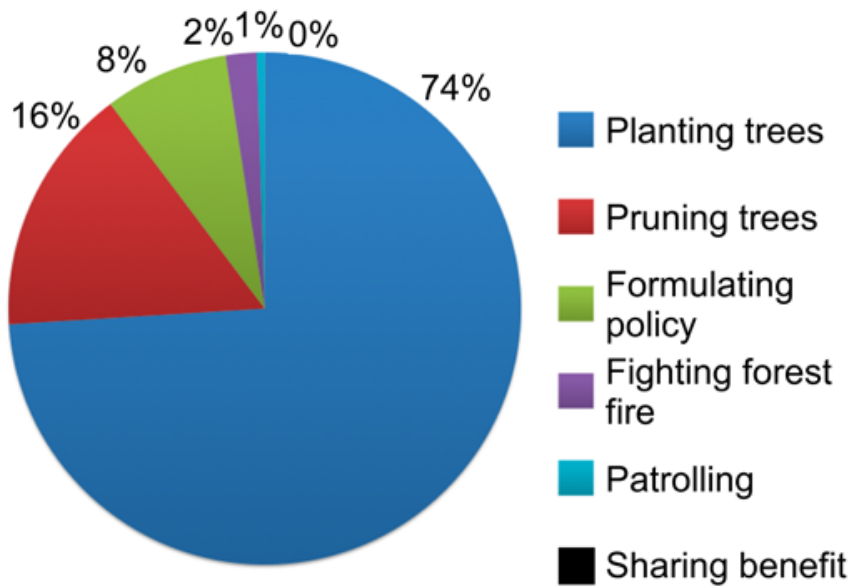

Figure 11. Activities carried out by CFA members as of 2015, identified by the questionnaire survey $(n=204)$.

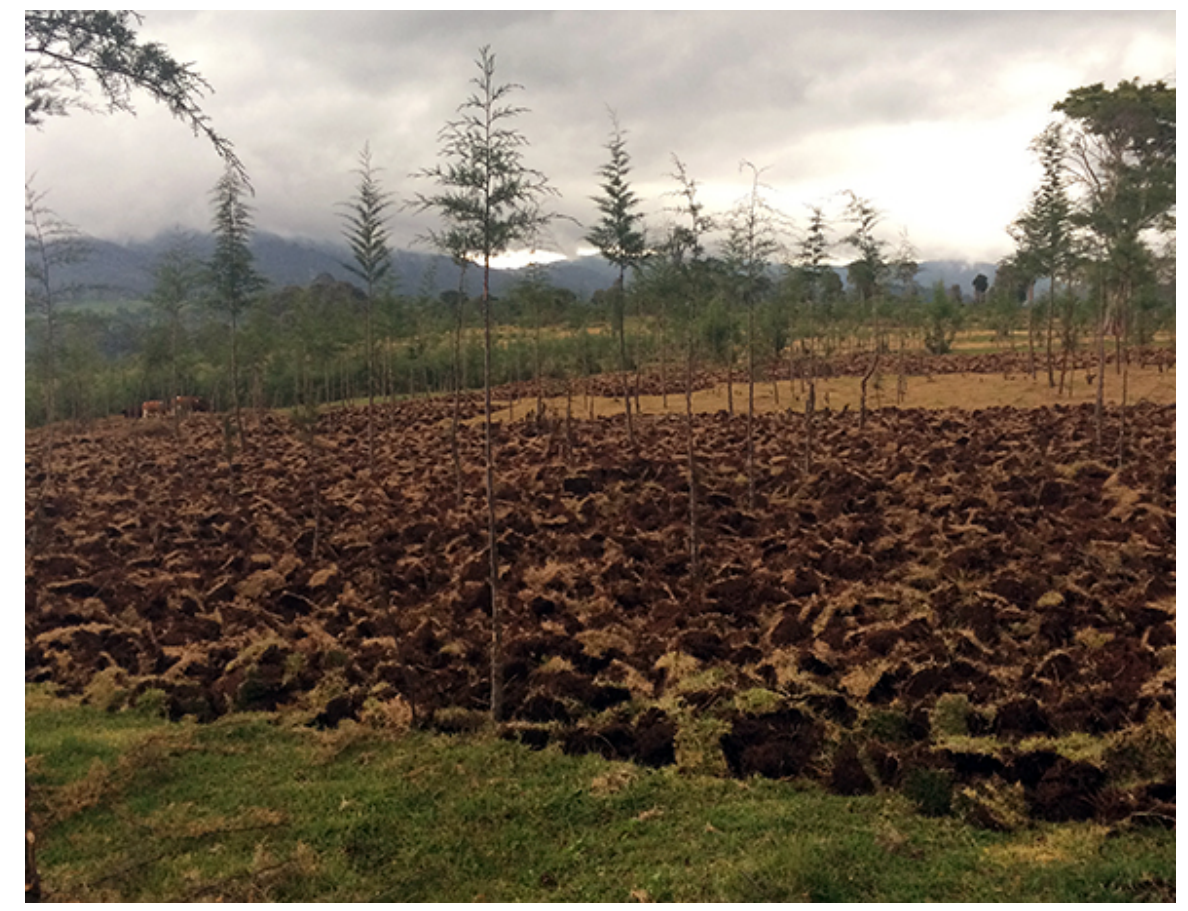

Figure 12. Reforestation programme in the Chemorgok Forest Block (Photo: Donald Kipruto Kimutai, 18 July 2015). 


\section{Discussion}

The forest-cover change analysis in the Lembus Forest revealed a decline in its cover in both the 1 st and 2 nd periods. The annual rates of forest-cover change varied greatly in both the 1 st and 2nd periods. Forest-cover declined at an annual rate of $0.4 \%$ in the 1 st period and $0.2 \%$ in the 2 nd period. The loss in forest-cover in both periods resulted from dynamic interchanges among land-cover types (Table 5). The interchanges were mainly attributed to increasing human activities within the forest. Although natural factors could also play a role in forest-cover change, the scope of this study mainly dwelt upon anthropogenic activities. Based on the interviews and field observations, it was evident that human activities were the main driver of forest-cover change.

In the 1st period, a significant amount of forest-cover (closed and open forests) was converted to barren land and grassland (Table 5). The conversion resulted from a government action to excise nearly 3700 ha of forest through legal notice number 203 of 1988 [43]. The excision contributed to rapid forest-cover decline in the 1st period. Some regions still remain part of the forest, although most excised areas have been excluded from the current forest boundary. Forest decline was driven by a number of underlying factors, such as the increasing human population (Figure 7), which exerted pressure on limited land resources, thus causing a shortage of land for settlement and cultivation. With the majority of respondents (63\%) depending on farming as their main economic activity (Figure 8), communities have encroached and cleared forests to create room for settlement and farming, thus contributing to forest-cover decline [10]. Inadequate reforestation programmes as a result of inadequate funding and lack of adequate personnel hindered reforestation of areas that underwent clear-cutting in the 1st period (Figure 13). However, conflicts between PELIS user groups and grazers who rely mostly on the forest for grazing their livestock (Figure 9) further slowed reforestation. Generally, forest recoveries experienced in the 1st period were attributed to natural regeneration.

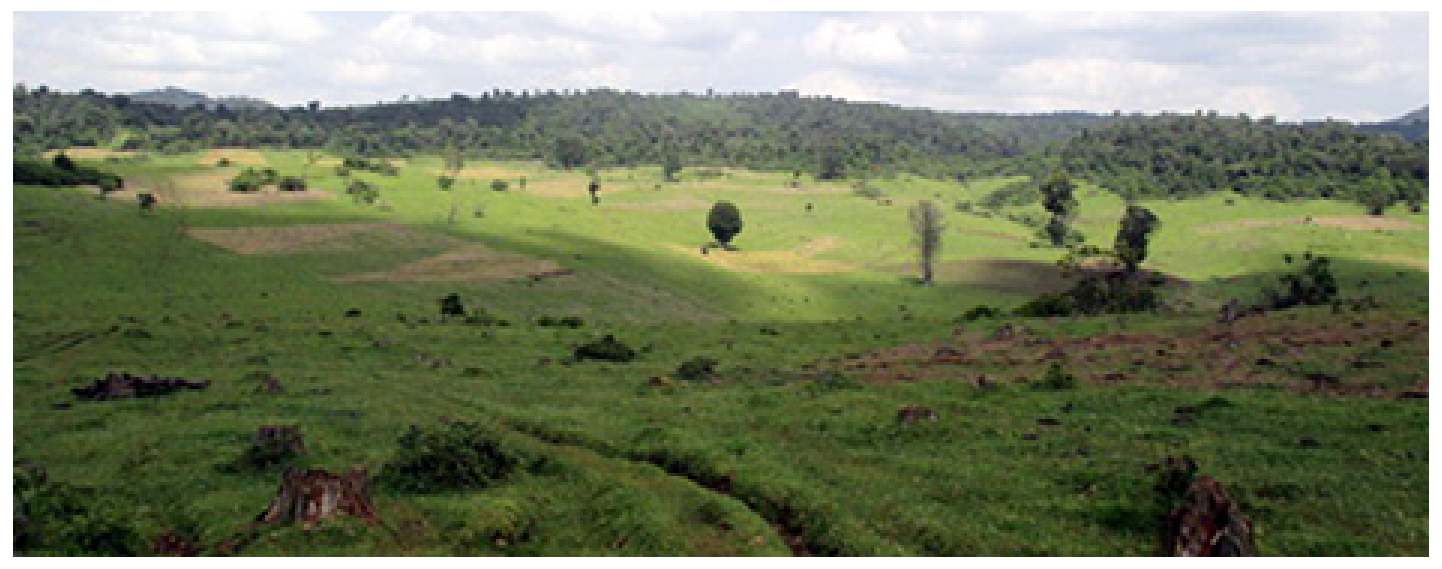

Figure 13. Part of the Chemususu Forest Block that underwent clear-cutting (Photo: Donald Kipruto Kimutai, 18 July 2015).

In the 2nd period, the Lembus Forest-cover continued to experience conversion to other land-cover; nevertheless, the results in Table 4 clearly show that the rate of conversion was lower during this period than that during the 1st period. The main factors attributed to forest-cover decline during this period were logging, encroachment, and infrastructural development. Both legal and illegal logging occurred during this period, although the number of cases of legal logging (harvesting of trees by KFS) decreased marginally during the 2 nd period. The decrease in the number of cases of legal logging was the result of the 1999 presidential ban on logging within all government forests. The ban on legal logging, however, was later lifted in early 2015. Yet, illegal logging continued to manifest in the forest (Table 10). The occurrence of illegal logging may be due to the local communities' heavy dependence on the forest. Rampant illegal logging affects both indigenous and exotic tree species; 
however, cedar trees have been highly affected by illegal logging due to higher demand for cedar posts by local people. Cedar trees are felled (Figure 14) and chopped into cedar posts, which local people use to construct both houses and fences.

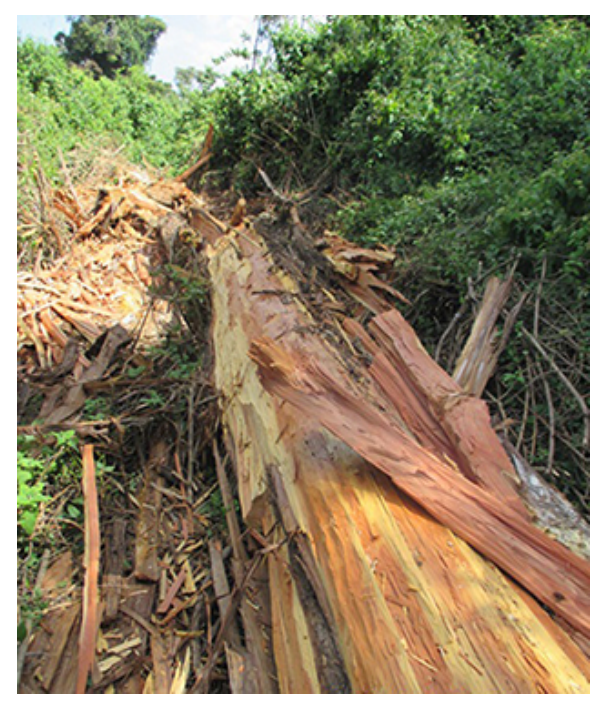

Figure 14. Illegal logging of cedar trees in the forest (Photo: Donald Kipruto Kimutai, 18 July 2015).

The fight against illegal logging has been hampered by the shortage of KFS personnel and the inability of CFAs to carry out all their mandates as stipulated in the 2005 Forest Act. Although the act empowers the CFAs to manage, protect, and conserve the forests, the members of the three CFAs have not yet participated in forest patrol, as shown in Figure 11. The operations of the CFAs have been hindered by a number challenges, which include the delay in the signing of the forest agreement, lack of funding, poor leadership, and insufficient power to carry out their mandate. For example, though the CFAs have established user groups, the KFS does the collection of forest revenue from the user groups, thus denying CFAs any chance of accessing forest revenue. The three CFAs, therefore, rely solely on the annual membership fee of one hundred shillings per member and donations, the latter of which are often not forthcoming. Lack of reliable income has hampered CFA operations; for example, LENCOFA and LCCFA tree nurseries are poorly maintained due to lack of funding for hiring staff to manage and maintain the nurseries. Other challenges facing CFAs include leadership conflicts among CFA members and poor record keeping, as made evident by LENCOFA (Table 9). Although the three CFAs have already developed their respective forest management plans, they have not been empowered to implement their forest management plan, which goes a long way in enhancing sustainable forest conservation and management. Our findings show that these obstacles are not peculiar to this area alone, but CFAs in other parts of the country face similar challenges $[16,17,19]$.

In spite of the challenges, the CFAs have made significant contributions to the development and management of tree plantations in their respective forest blocks. The reforestation programmes carried out by the CFAs received a boost following KFS' introduction of the PELIS programme. Through the programme, non-forested regions are allocated to CFA members to cultivate and later plant trees. Thus, after CFA members have used the land for agriculture, they provide free labour for planting and maintaining trees within their respective plots. The result is an emergence of plantations in areas initially dominated by grassland (Figure 12). These findings relate well with other studies that have acknowledged the significant role of CFAs in reforestation programmes $[13,18,19]$.

The three forest blocks of this study show the different changes in forest-cover in the 1st and 2nd periods. Figures 3-5 show that more non-forest areas exist in the margins of the blocks, suggesting the need to introduce different types of forestry stewardship measures. In addition, Figure 5 shows that the Narasha Forest Block suffers from severe fragmentation, suggesting the need for urgent 
measures. Even though the Lembus Forest as a whole showed a significant decline in the rate of forest-cover, the three forest blocks forming the Lembus Forest have experienced certain variations in their forest-cover change dynamics. For example, forest-cover in the Chemorgok Forest Block has remained stable in both the 1st and 2nd periods, with slight forest recovery slowing the rate of the forest-cover decline in the 2nd period. The increase in the recovery was attributed to the reforestation programme by the CFA as well as natural regeneration. Moreover, the forest block has experienced a decrease in percentage of forest decline in the 2nd period, even with illegal logging and forest encroachments still occurring in the 2nd period. The Chemususu Forest Block, however, revealed a totally different pattern: despite forest-cover remaining dominant in both periods, the percentage of forest decline was higher in the 2nd period compared with that of the 1st period. The increase in the percentage of forest decline resulted from the clearance of forest-cover to pave the way for dam construction in the Chemususu Forest Block. Illegal logging may have also contributed to the decline. Furthermore, our results show that the highly fragmented Narasha Forest Block experienced forest-cover decline to less than $50 \%$ of the total land area. In comparison to the Chemorgok and Chemususu Forest blocks, the Narasha Forest Block had the lowest forest-cover and a high percentage of forest-cover decline. Although the percentage of forest decline showed a significant decrease, the percentage of non-forest plantation remains high. The higher rates of illegal logging and forest encroachment may have resulted from high population pressure.

\section{Conclusions}

The Lembus Forest's land-cover has been shaped by human activity that includes logging, encroachment, excision, and infrastructural development. To comprehend the impacts resulting from human activity, this study estimated the changes of forest-cover, analysed them, and assessed the dynamics of forest-cover loss occurring in the 1st period (before operation of the PFM) and during the 2nd period (after operation of the PFM). The results clearly reveal a decline in the Lembus Forest-cover in both the 1st and 2nd periods. Nevertheless, the annual rate of forest-cover loss significantly decreased from the initial annual rate of $0.4 \%$ in the 1 st period to $0.2 \%$ in the 2 nd period. The drastic decline in the rate of forest-cover loss may have resulted from reforestation programmes carried out by CFA members in the 2nd period. Although CFA members have actively participated in reforestation programmes, other equally important CFA roles have not yet been fully implemented in all three forest blocks due to delays in signing forest management agreements between the CFAs and KFS. In addition, the CFAs face a number of challenges, including a lack of funding and leadership conflicts, both of which have hindered the effectiveness and efficiency of CFAs in the management and conservation of forests.

Acknowledgments: A part of the study was possible with the financial help from the Japan International Cooperation Agency (JICA).

Author Contributions: Donald Kipruto Kimutai performed the field survey; Donald Kipruto Kimutai and Teiji Watanabe analysed the data; and wrote the paper.

Conflicts of Interest: The authors declare no conflict of interest. The founding sponsors had no role in the design of the study; in the collection, analyses, or interpretation of data; in the writing of the manuscript, and in the decision to publish the results.

\section{Abbreviations}

The following abbreviations are used in this manuscript:

CFA Community Forest Association

PFM Participatory Forest Management

KFS Kenya Forest Service

PELIS Plantation Establishment and Livelihood Improvement Scheme 


\section{References}

1. Chao, S. Forest Peoples: Numbers Across the World; Forest Peoples Programme: Moreton-in-Marsh, UK, 2012.

2. Miura, S.; Amacher, M.; Hofer, T.; San-Miguel-Ayanz, I.; Thackway, R. Protective functions and ecosystem services of global forests in the past quarter-century. For. Ecol. Manag. 2015, 352, 35-46. [CrossRef]

3. Food and Agricultural Organization of the United Nation (FAO). State of the World's Forest: Enhancing the Socio Economic Benefits from Forests; FAO: Rome, Italy, 2014.

4. Vedeld, P.; Angelsen, A.; Bojö, J.; Sjaastad, E.; Berg, C.K. Forest environmental incomes and the rural poor. For. Policy Econ. 2007, 9, 869-879. [CrossRef]

5. Babulo, B.; Muys, B.; Nega, F.; Tollens, E.; Nyssen, J.; Deckers, J.; Mathijs, E. The economic contribution of forest resource use to rural livelihoods in Tigray, Northern Ethiopia. For. Policy Econ. 2009, 11, 109-117. [CrossRef]

6. Food and Agricultural Organization of the United Nation (FAO). State of the World's Forest; FAO: Rome, Italy, 2012.

7. Food and Agricultural Organization of the United Nation (FAO). Global Forest Assessment; FAO: Rome, Italy, 2010.

8. Hansen, M.C.; Potapov, P.V.; Moore, R.; Hancher, M.; Turubanova, S.A.; Tyukavina, A.; Kommareddy, A. High-resolution global maps of 21st-century forest cover change. Science 2013, 342, 850-853. [CrossRef] [PubMed]

9. Mwagore, D. Land Use in Kenya: The Case for a National Land-Use Policy; Kenya Land Alliance: Nakuru, Kenya, 2003; Volume 3.

10. Lambrechts, C.; Gachanja, M.; Woodley, B. Maasai Mau Forest Status Report $2015 . \quad$ Available online: http://www.iapad.org/wp-content/uploads/2016/01/maasai_mau_report-1.pdf (accessed on 30 April 2016).

11. Ongong'a, I.A.; Sweta, L. Land cover and land use mapping and change detection of Mau Complex in Kenya using geospatial technology. Int. J. Sci. Res. 2014, 3, 767-778.

12. Ongugo, P.O.; Mogoi, J.N.; Obonyo, E.; Oeba, V.O. Examining the Roles of Community Forest Associations (CFAS) in the Decentralization Process of Kenyan Forests. Available online: https:/ /vtechworks.lib.vt.edu/ bitstream/handle/10919/68266/3655_Ongugo_220301.pdf?sequence=1 (accessed on 30 April 2016).

13. Mutune, J.M.; Lund, J.F. Unpacking the impacts of "participatory" forestry policies: Evidence from Kenya. For. Policy Econ. 2016, 69, 45-52. [CrossRef]

14. Government of Kenya (GOK). Laws of Kenya, the Kenya Forest Act, 2005. Available online: http://www.law.pace.edu/sites/default/files/IJIEA/ForestsAct2005.pdf (accessed on 30 April 2016).

15. KFS. Kenya Forest Service. Available online: http://www.kenyaforestservice.org (accessed on 10 April 2016).

16. Chomba, S.; Nathan, I.; Minang, P.A.; Sinclair, F. Illusions of empowerment? Questioning policy and practice of community forestry in Kenya. Ecol. Soc. 2015, 20, 2. [CrossRef]

17. Koech, C.K.; Ongugo, P.O.; Mbuvi, M.T.E.; Maua, J.O. Community Forest Associations in Kenya: Challenges and Opportunities; Kenya Forestry Research Institute: Nairobi, Kenya, 2009.

18. Agevi, H.; Wabusya, M.; Tsangalia, H.M. Community forest associations and community based organisations: Redesigning their roles in forest management and conservation in Kenya. Int. J. Sci. Res. 2014, 3, 1916-1922.

19. Mogoi, J.; Obonyo, E.; Ongugo, P.; Oeba, V.; Mwangi, E. Communities, property rights and forest decentralisation in Kenya: Early lessons from participatory forestry management. Conserv. Soc. 2012, 10, 182-194.

20. Matiku, P.; Caleb, M.; Callistus, O. The impact of participatory forest management on local community livelihoods in the Arabuko-Sokoke Forest, Kenya. Conserv. Soc. 2013, 11, 112-129. [CrossRef]

21. Mbuvi, M.T.E.; Musyoki, J.K. Impacts of participatory forest management on community livelihoods: A case study of Dida Community adjacent to Arabuko-Sokoke forest in Kilifi County, Kenya. World J. Agric. Sci. 2013, 1, 44-55.

22. Nagendra, H.; Karmacharya, M.; Karna, B. Evaluating forest management in Nepal: Views across space and time. Ecol. Soc. 2005, 10, 24.

23. Birendra, K.C.; Mohammod, A.J.; Inoue, M. Community forestry in Nepal's Terairegion: Local resource dependency and perception on institutional attributes. Environ. Nat. Resour. Res. 2014, 4, 142-154. 
24. Porter-Bolland, L.; Ellis, E.A.; Guariguata, M.R.; Ruiz-Mallén, I.; Negrete-Yankelevich, S.; Reyes-García, V. Community managed forests and forest protected areas: An assessment of their conservation effectiveness across the tropics. For. Ecol. Manag. 2012, 268, 6-17. [CrossRef]

25. Ellis, E.A.; Porter-Bolland, L. Is community-based forest management more effective than protected areas? A comparison of land use/land cover change in two neighboring study areas of the central Yucatan Peninsula, Mexico. For. Ecol. Manag. 2008, 256, 1971-1983. [CrossRef]

26. Coppin, P.; Jonckheere, I.; Nackaerts, K.; Muys, B.; Lambin, E. Review Article Digital change detection methods in ecosystem monitoring: A review. Int. J. Remote Sens. 2004, 25, 1565-1596. [CrossRef]

27. Hayes, D.J.; Cohen, W.B. Spatial, spectral and temporal patterns of tropical forest cover change as observed with multiple scales of optical satellite data. Remote Sens. Environ. 2007, 106, 1-16. [CrossRef]

28. Kenya National Bureau of Statistics (KNBS). Kenya Population and Housing Census; KNBS: Nairobi, Kenya, 2009.

29. Israel, G.D. Determining Sample Size. Available online: http://edis.ifas.ufl.edu/pd006 (accessed on 30 April 2016).

30. Wass, P. Kenya's Indigenous Forests; IUCN: Gland, Switzerland; Cambridge, UK, 1995.

31. Chavez, P.S. Image-based atmospheric corrections-revisited and improved. Photogramm. Eng. Remote Sens. 1996, 62, 1025-1035.

32. Chander, G.; Markham, B.L.; Helder, D.L. Summary of current radiometric calibration coefficients for Landsat MSS, TM, ETM+, and EO-1 ALI sensors. Remote Sens. Environ. 2009, 113, 893-903. [CrossRef]

33. Czapla-Myers, J.; Joel McCorkel, J.; Anderson, N.; Thome, K.; Biggar, S.; Helder, D.; Aaron, D.; Leigh, L.; Mishra, N. The ground-based absolute radiometric calibration of Landsat 8 OLI. Remote Sens. 2015, 7, 600-626. [CrossRef]

34. Carlson, T.N.; Ripley, D.A. On the relation between NDVI, fractional vegetation cover, and leaf area index. Remote Sens. Environ. 1997, 62, 241-252. [CrossRef]

35. Mas, J.-F. Monitoring land-cover changes: A comparison of change detection techniques. Int. J. Remote Sens. 1999, 20, 139-152. [CrossRef]

36. Domenikiotis, C.; Dalezios, N.R.; Loukas, A.; Karteris, M. Agreement assessment of NOAA/AVHRR NDVI with Landsat TM NDVI for mapping burned forested areas. Int. J. Remote Sens. 2002, 23, 4235-4246. [CrossRef]

37. Weiss, J.L.; Gutzler, D.S.; Allred Coonrod, J.E.; Dahm, C.N. Long-term vegetation monitoring with NDVI in a diverse semi-arid setting, central New Mexico, USA. J. Arid Environ. 2004, 58, 249-272. [CrossRef]

38. Pettorelli, N.; Vik, J.O.; Mysterud, A.; Gaillard, J.-M.; Tucker, C.J.; Stenseth, N.C. Using the satellite-derived NDVI to assess ecological responses to environmental change. Trends Ecol. Evol. 2005, 20, 503-510. [CrossRef] [PubMed]

39. Sobrino, J.A.; Raissouni, N.; Li, Z.-L. A comparative study of land surface emissivity retrieval from NOAA data. Remote Sens. Environ. 2001, 75, 256-266. [CrossRef]

40. USGS. Remote Sensing Phenology. Available online: http://phenology.cr.usgs.gov/ndvi_foundation.php (accessed on 1 January 2015).

41. Puyravaud, J.-P. Standardizing the calculation of the annual rate of deforestation. For. Ecol. Manag. 2003, 177, 593-596. [CrossRef]

42. Congalton, R.G. A review of assessing the accuracy of classifications of remotely sensed data. Remote Sens. Environ. 1991, 37, 35-46. [CrossRef]

43. Matiru, V. Forest Cover in Kenya, Policy and Practice; IUCN-World Conservation Union: Nairobi, Kenya, 2000.

(c) 2016 by the authors; licensee MDPI, Basel, Switzerland. This article is an open access article distributed under the terms and conditions of the Creative Commons Attribution (CC-BY) license (http://creativecommons.org/licenses/by/4.0/). 